\title{
META-ANALYSIS: THE RELATIONSHIP BETWEEN OLDER AGE AND DEATH CAUSED BY COVID-19
}

\author{
Annissa Devi Permata1), Bhisma Murti'), Didik Gunawan Tamtomo²) \\ ${ }^{1)}$ Masters Program in Public Health, Universitas Sebelas Maret \\ ${ }^{2)}$ Faculty of Medicine, Universitas Sebelas Maret
}

\begin{abstract}
Background: The older people tended to have more severe illness conditions and vulnerable on infectious disease, including COVID-19. Previous studies reported that the highest fatality rates are older people, across countries with varying levels of COVID-19 mortality and infection. This study aimed to investigate older age as a risk factor of COVID-19 mortality using meta analysis.

Subjects and Method: A systematic review and meta-analysis was conducted by PRISMA flow diagram. The articles were collected from PubMed, Science Direct, Springer Link, and PMC Europe databases. Keywords used "older age" AND "mortality" OR "death" OR "fatal outcome" OR "Predictors outcome" OR "Impact" AND "coronavirus" OR "Covid-19" OR "SARS-COV-2" OR "2019 n-Cov" OR "severe acute respiratory syndrome related coronavirus". The inclusion criteria were full text, articles were published from year 2020 to 2021, retrospective cohort studies, used English language, and reported adjusted Odds Ratio. Articles that met the criteria were analyzed by Revman 5.3.

Results: 7 articles were included into a meta analysis study. This study showed that older age had risk 4.15 times to death caused by COVID-19 infection than younger age $(\mathrm{aOR}=4.15 ; 95 \% \mathrm{CI}=2.35$ to $7.32 ; \mathrm{p}<0.001)$.

Conclusion: Older age increased the risk of death caused by COVID-19 infection.
\end{abstract}

Keywords: death, COVID-19, older age

\section{Correspondence:}

Annissa Devi Permata. Masters Program in Public Health, Universitas Sebelas Maret. Jl. Ir. Sutami, 36A, Surakarta 57126, Central Java. Email: 96annissadevipermata@gmail.com.

The $8^{\text {th }}$ International Conference on Public Health Solo, Indonesia, November 17-18, 2021 | 23 https://doi.org/10.26911/AB.Epidemiology.ICPH.08.2021.03 